\title{
Lapurdum
}

LAPURDUM Euskal ikerketen aldizkaria | Revue d'études basques |

Revista de estudios vascos | Basque studies review

$7 \mid 2002$

Numéro VII

\section{Kausazio aldizkatzea euskal aditzetan}

\section{Bernard Oyharçabal}

URL : http://journals.openedition.org/lapurdum/1024

DOI : $10.4000 /$ lapurdum. 1024

ISSN : 1965-0655

Éditeur

IKER

\section{Édition imprimée}

Date de publication : 1 octobre 2002

Pagination : 271-294

ISBN : 2-86781-321-2

ISSN : 1273-3830

\section{Référence électronique}

Bernard Oyharçabal, « Kausazio aldizkatzea euskal aditzetan », Lapurdum [Linean], 7 | 2002, Sarean emana----an 01 juin 2009, kontsultatu 19 avril 2019. URL : http://journals.openedition.org/ lapurdum/1024; DOI : 10.4000/lapurdum.1024 


\title{
Kausazio aldizkatzea euskal aditzetan
}

\author{
Bernard OYHARÇABAL
}

IKER UMR 5478 CNRS

Aditz kausatiboetan bi erabide bereziki kausitzen ditugu ${ }^{2}$ Horrela, (1)eko adibideko formaren aurrean, (2)ko adibideetan aurkitzen ditugu aditz kausatiboak:
(1) Katua hil da
(2a) Katua hil dut
(2b) Katua hilarazi dut

Hiru adibide horietan aditz bera agertzen zaigu (hil), edo aditz laguntzaile iragangaitzarekin (1), edo irangankorrarekin (2a,b). Ohargarria da perpaus horietan agertzen den DS absolutiboak (katua), nahiz funtzio sintaktiko desberdinak dituen (subjektuarena (1)ean, objektuarena (2a,b)etan), beti thetaerrol bera duela: aditzak adierazten duen egoera aldaketan temari dagokiona. (1) adibidean, hil aditz monadikoa da. Haren subjektua, (2a,b)etako perpausetan objektu gisa agertzen dena, aditzaren hurbileko barne-argumentua da, eta subjektu posiziora mugitu da. (2a,b) adibideetan, (1)eko prozesu bera denotatua da gisa batez (katuaren hiltzea), baina zerk eragin duen zehaztuz. Eragite hori bi adibideetan ez da modu berean gertatzen, eta era desberdinetan adierazia da, nahiz bietan zehazten den subjektuak zerbait egin duela katuaren hiltzea ekarri edo eragin duena. Eragite horri erranen diogu kausazioa, eta $(2 \mathrm{a}, \mathrm{b})$ aditzei, kausazio aditzak edo aditz kausatiboak, subjektua bi kasuetan arazle (causer) izanik. Comrieren (1989) tipologiako izendapenak baliaturik, kausatibo lexikalak eta kausatibo morfologikoak dei daitezke hurrenez hurren $(2 \mathrm{a}, \mathrm{b})$ aditzak eta perpausak. (1-2a) adibideetan aditzarekin nabarmentzen den jokoari, idazlan honen ikergaia izanen denari, kausazio aldizkatze lexikala, erranen diogu.

${ }^{I}$ Ikerketa hau Syntaxe lexicale du basque deitu programan (PICS 1999-2002, CNRS) baten barneko lana da. Aurreko bertsio bat argitaratzekoa da ingelesez programa horretako argitalpenean (aurreratzen).

${ }^{2}$ Eskerrak bihurtzen dizkiot idazlan honen hobetzera lagundu nauen X. Artiagoitiari. Halaber, eskertu nahi ditut datuak biltzerakoan beren intuizioen berri eman didaten adiskide hauek: $P$. Altuna, A. Arkotxa, P. Charritton, R. Etxepare, I. Etxebeste, J. Haritschelhar, B. Hidalgo, D. Landart eta K. Segurola.

Laburduren azalpena: AS: aditz sintagma; DS: determinatzaile sintagma; IO: izenondoa; PospS: posposizio sintagma. 


\section{Kausazio perpausen ezaugarriak}

Dixonek (2000) erabide kausatiboen sailkatzeko zerrendatzen dituen bederatzi irizpideen arabera, euskal kausatiboen ezaugarriez denaz bezainbatean, batez ere hiru kontuan hartzekoak dira: lehena, oinarri aditzaren aspektuari dagokio; bigarrena, haren izaera sintaktikoari, eta hirugarrena arazlearen eraginaren zeiharkakotasunari.

Sarrera honetan, gure ikergaiaren mamia zehaztu aitzin, euskarazko kausazio perpausen itxura orokor baten emateko xedearekin, laburzki ikusiko ditugu hiru puntu horiek.

1.1. Dixonek aipatzen duen lehen puntua zehazki hau da: ea oinarri aditza egoera-aditza izan daitekeen ala ez. Euskaran garrantzizko puntua da, ez kausazio perpaus moten artean bereizkuntza bat sorrarazten duelako, baizik ere aditz mota edo predikatu horiekin ${ }^{4}$ (eduki, Izo/I/PospS izan/egon, (zerbaitetan) jakin, ...) kausatiborik ezin sorraraz daitekeelako, ez kausatibo lexikalik, ez eta kausatibo morfologikorik ere, hala nola ikus baitaiteke ondoko adibideetan:

\section{*Otoitzek saindu /parabisuan izan(arazi)ko zaituzte}

\section{* Semeari euskaraz (mintzatzen) jakin(arazi) diot}

Adibide horietan egoera predikatuak egitura kausatiboetan agerrarazten ditugu. Ikus dezakegu perpaus agramatikalak sortzen direla orduan. ${ }^{5}$

Kontuan har bedi, bizkitartean, aditz morfologia iragankorra aise erabil daitekeela euskaran egoera predikatu zenbaitekin, hala nola kopula perpaus bat dutenekin. Haatik, ez zaie interpretazio kausatiborik ematen Rebuschik (1984) inplikatibo deitu zituen holako perpausei:

\section{(3c) Lankidea aitzinean / aspaldiko adiskidea / eri / hotzak hila dut (daukat)}

Adibide horretan, PS / IS / IzoS + IZAN (edo EGON) egitura duen perpaus nominala dugu. Kanpoko argumentua izanagatik, (3c) perpausari ez zaio interpretazio kausatiboa ematen.

1.2. Bigarren puntua, oinarri aditzaren izaera sintaktikoari dagokiona, honela formula daiteke Dixonen (2000) tipologiari jarraikiz: ea aditz hura iragankorra izan daitekeen edo ez. Ondorio zuzena du puntu honek euskaran, kausatibo lexikalik ezin sor baitaiteke oinarri aditz iragankor batetik, bai ordea, arazorik gabe, kausatibo morfologikoak. Ondoko adibideek hori erakusten dute:

$$
\text { Autoa garajean sartu dut }
$$

Autoa garajean *sartu / sarrarazi didazu

Sagarra jan dut

Sagarra *jan / janarazi didazu

${ }^{3} \mathrm{Ez}$ ditut kontuan hartzen hemen -ra- morfemaren bidez moldatzen diren kausazio aditzak, erabide eihartu bati baitagozkio. Kontrol perpausak dakartzaten behartu edo bortxatu aditzen bidez eratzen direnak ere, baimen kausatiboak bezala (laga, utzi), ez ditut aipatuko.

${ }^{4}$ Egoera aditzez hemen erraten dena orokoregia bide da; halere, horrela utziko dut aurkezpen honetan.

${ }^{5}$ Kausalitatea konplidura-aditzekin agertu beharra dela adierazia izan da (Dowty 1979). Ikus halere, honen aurka, Pylkkänen (1999). 
Ikus daitekeenaz, (4a,c) adibideetako perpaus iragankorra egitura kausatibo batean erabiliz gero $(4 \mathrm{~b}, \mathrm{~d})$, erabide morfologikoa bakarrik erabil daiteke (sarrarazi, janarazi), aditzaren beste formak (sartu, jan) interpretazio kausatiboa ezin izan baitezake. ${ }^{6}$

1.3. Dixoni (2000) beti jarraikiz, aipatu nahi dugun hirugarren puntua honetan datza: ea arazlearen eragina zeiharkakoa ala zuzena den. Aski lausoa da kontu hau, hizkuntzatik kanpora errazki lerraraz gaitzakeena, hizkuntzaz kanpoko munduan azken katebegi bat beti gainera dakiokeen katea bezala agertzen baita kausalitatea. Bizkitartean, Dixonek oharrarazten duen bezala, badu honek eragin nabarmena kausatiboetan, eta euskaran ere bai. Ondoko adibideek hori 'erakusten dute:

(5a) * Oswaldek tiroz hilarazi zuen Kennedy vs Oswaldek tiroz hil zuen Kennedy

(5c) *Erregeak gosez hil zuen presoa vs Erregeak gosez hilarazi zuen presoa

- (5a) adibidean, kausatibo morfologikoa desegokiro erabilia da, zeren Oswaldek berak tiro egin baitzion Kennedyri. Aitzitik, kausatibo morfologikoa baliatuz besterik erraten da, Oswald zeiharkako arazlea (eta ez tiro egilea) izan zela adieraztera emanez.

- (5b) adibidean, kausatibo lexikala da modu desegokian erabilia. Izan ere, hura enplegatuz, adieraztera ematen da Francok berak tiro egin ziola hiltzera kondenarazi zuen Grimauri, ez baitzen hala gertatu.

- (5c) adibidean ere, kausatibo lexikala gaizki erabilia da. Gosez hiltzeak inplikatzen du gosea bera izan zela hiltzearen eragile zuzena. Altabada, arazleak ezin dezake zuzenean hura kontrola edo tresnatzat eduki (hizkuntzaren ikuspegitik, behintzat). Kausatibo lexikala tokiz kanpo erabilia da, beraz, perpaus hartan, zeren arazlearen eragina zeiharkakoa baita. Ohargarria da, adizlagun gisa, gosez erran ordez, ezpataz edo tiroz, erabiltzen bada (hots, arazleak osoki kontrolatzen duen tresna edo bitartekoa izanik adizlagunaren ardatza), perpausa egokiro eraturik gelditzen dela, orduan arazlearen eragina zuzena baita:

(5d) Erregeak ezpataz hil zuen presoa.

1.4. Aurkezpen orokor honen ondoan, derradan azterketa honen helburua, kausatibo lexikalei dagokien kausazio aldizkatze lexikala (1-2a) euskaraz nola gertatzen den ikertzea dela. Horretarako, lehenbizikorik, gai horren ikertzeko aitzinatu izan diren hurbilpen teoriko nagusiak laburzki gogoratu ditugu, hemengo idazlanean, deskonposizio lexikalari darraiona hobetsiko dugula adieraziz ( $(2)$. Ondotik, aztertuko dugu zer ondorio duen horrek aditz kausatibo lexikalei dagozkien baldintza sintaktikoentzat (\$3). Erakustera emanen dugu, gorago aipatu dugun muga sintaktikoa (aditz iragankorrek kausatibo lexikalei ez dietela biderik irekitzen), zuzena izanagatik, kontuaren parte bat baizik ez dela, eta aditz iragangaitzetan ere mugatua dela kausatibo lexikaletan ager daitezkeen aditzen saila. Mugatze hori aditzen kasu-morfologiari lot ote dakiokeen ikusiko

${ }^{6}$ Bestalako interpretazioa emanez gero, datibo benefaktibo batekin, perpausa ongi eratua da, noski. 
dugu ondotik, [+ERG] diren aditz iragangaitzak ia salbuespenik gabe, kausatibo lexikaletan ezin ager daitezkeela erakustera emanez. Baina hor ere urrunago joan beharra dela ageriko da, zeren [-ERG] diren aditzetan ere sail batzuk baitira kausatibo lexikaletan ezin erabiliak direnak, bai NOR-NORI aditzetan bai NOR bakarra dutenetan. Euskarazko kausatibo lexikalak, aldaketa aditzekin (esperientzorea objcktu gisa dakarten psiko-aditz kausatiboak barne) bakarrik eratzen direla ondorioztatuko dugu. Erabide honen azalpen gisa erranen dugu kausatibo lexikaletako kausa buruak araberako predikatuak (BIHUR / JOAN) aukeratzen dituela, kontrastea izanik orduan kausatibo morfologikoekin, non bestelako osagai sintaktikoak (BozS) aukeratuak baitira. Bukaerako ( 6 ), Araz burua eta kanpoko argumentua dakarren $B o z$ burua elkarretarik bereitzen dituen Pylkkänen (2002) tipologia onartuz, euskara, ingelesa bezala, bi buruak bateratzen dituen hizkuntza dela ondorioztatuko dugu.

\section{Kausazio perpausen azalpen lexikala eta sintaktikoa}

Aditzaren argumentuen kopuruari edo adierazteko moduen aldaketari josiak diren beste alternantzia sintaktikoetan bezala (izen inkorporazioa, pasibazioa, aplikatiboak, ...), kausatibo lexikaletan ere agertzen da lexikoiaren eta joskeraren arteko harremanen arazoa. Ikusmoldeak bi multzotan sailka daitezke: hipotesi lexikalista deitu izan denari jarraikitzen zaizkionak, eta hipotesi sintaktikoa segitzen dutenak.

2.1. Ikuspegi lexikalistan kausazio aldizkatzea lexikoitik bideratua da, Islapen Hatsarreari segituz (Chomsky 1981). Lexikoiko sarrera bakoitzak argumentu egitura du aditzaren esanahiari lotua, eta joskeran islatzen dena. Kausatibo lexikalen kasuan, maila horretan berean, lexikoian, agertzen da aditzaren bikoiztasuna, gisa batez edo bestez bi argumentu egitura desberdin baitagozkie aditzaren bi erabilerei, nahiz desberdintasuna sistematikoa den eta franko mugatua, kanpoko argumentu bat izatean edo ez izatean baitatza. Ikuspegi horretan, kausazio aldizkatzea bi modutan azaldua izan da lexikoian: edo argumentu gehitze gisa, edo argumentu gutitze gisa.

Argumentu gehitzearen alde jotzen duten ikerbideetan (Williams 1981), kausazio aldizkatzea duten aditzen argumentu egituran arazle argumentu bat gehitzen zaio aditz monadikoari, honek orduan forma diadikoa hartzen baitu, hala nola gertatzen baita, hiztegiko bi sarrera desberdinekin, kausatibo labileetan (kill vs die). Azterbide hau da EGLU-IIan aurkitzen dena eta hemen gogoratzen duguna:

$$
\begin{array}{cccc}
\text { hil }_{1} & \text { hil }_{2} & (\text { EGLU-II, 52) } \\
\text { [NOR] } & \rightarrow & \begin{array}{c}
\text { NOR-NORK] } \\
\text { +arazlea }
\end{array} &
\end{array}
$$

Argumentu gutitzea aldezten duten azterketetan (Levin \& Rappaport Hovav 1995, Jackendoff 1997) alderantzizko jokabidea hobesten da, eta beraz kausazio aldizkatzea kausatibatze gisa aztertzeko orde, deskausatibatze gisa egiten da. Errepresentazio semantikoan aditzak kanpoko argumentuari dagokion thetaerrola badu, baina argumentu egituran ez da agertzen eta, ondorioz, ez joskeran islatzen. Azterbide honetan aditz inakusatiboen lexikoi errepresentazioaren oinarrian kausazio egitura aurkitzen da, eta hain zuzen, anitz hizkuntzatan morfologian berean ikus daiteke hau, zeren kausazio aldizkatzea duten aditzetan forma bat markatua denean, hura forma iragangaitza ohi baita. Levin \& Rappaport Hovavek (1995:80-81) diotenaz, Chierchiak (1989) aldizkatze inkoatiboa-kausatiboa duten mintzaira erromanikoentzat agerian ematen du puntu hori, aditz inakusatiboek forma pronominala izanki, eta kausatiboek, 
aldiz, forma biluzia. ${ }^{7}$ Levin eta Rappaport Hovavek ere ikusmolde hau beretzen dute, eta aditz inakusatiboez eskaintzen duten azalpen orokorrean garatzen: haien azterbidean, Lexikoi-Kontzeptu Egituran (Lexical Conceptual Structure) errepresentzio bakarra du aldizkatze lexikala duen aditzak, baina bi argumentu egitura ditu (bat diadikoa -kausatiboa-, eta bestea monadikoa). Kanpoko argumentua desagerrarazten duen lexikoi uztardura (lexical binding) delakoaren bidez azaltzen dute zergatik ez den islatzen aditz inakusatiboen argumentu egituran Lexikoi-Kontzeptu Egiturako kanpoko argumentua, ebento arazleko egileari dagokiona. Azterbide honetan, honela agertzen dira hil aditzaren altzernantziako bi lexikoi-errepresentazioak (cf. Levin \& Rappaport Hovav 1995:108).

Hil inakusatiboa - hil : $<\mathrm{y}>$

$[[\underset{\downarrow}{x}$ DO-SOMETHING] CAUSE [ $y$ BECOME hil $]$

Lexikoi uztardura

Lotura erregelak

Argumentu egitura

$\emptyset$

Hil kausatiboa - hil : $\mathrm{x}<\mathrm{y}>$

Lotura erregelak

Argumentu egitura

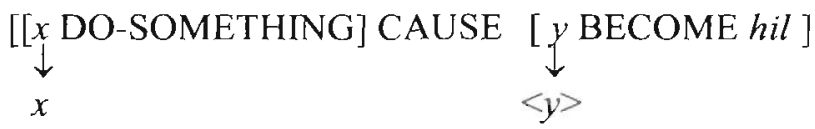

Gorago aipatu azterbideetan ikusi bezala, lexikoian berean, argumentu egitura antolatzeko eran, azaltzen da aldizkatze kausatiboa, gero joskeran islatzen dena, hipotesi lexikalistak nahi duen bezala.

2.2. Beste ikuspegi bat kontrajarria izan zaio azterbide honi, non joskeran kokatzen baitira aldizkatzearen azterbideen oinarriak, gisa horretan semantika generatibistaren aspaldiko zenbait jokabideri jarraikiz (Lakoff 1968). Erregularitate sintaktikoei azalpen sintaktikoa eman zekiekeela erakutsi ondoan (cf. bereziki Baker 1988, eta euskal kausatibo morfologikoentzat Deustuko Mindegia 1989), berez bezala heldu zen gisa bereko azterbideak aldizkatze kausatiboentzat ere proposa zitezkeela. Minimalismoaren barnean egindako azalpenetan kanpo argumentuaren agerpena joskerako buru berezi bati lotua baita -Chomskyren (1995:352) a aditz arina, Kratzerren (1996) Boz burua-, azken urteetan modu desberdinetan landua izan da ikerbide hau (Megerdoomian 2002, Pylkkänen 2001, 2002, Folli \& Harley (bidean)). Guk ere bide bera segituko dugu hemen, erregularitate sintaktikoak, kausatibo lexikaletako alternantzietan agertzen direnak ere bai, joskeraren bidez azaltzeko direla proposatuz. Ikuspegi horretan, lexikoi deskonposizioa zuzenean joskerako printzipioen arabera bideratua da Hale \& Keyserrek (1993) proposatu bidetik, baina lexikoia joskeratik bereiz atxiki gabe, eta deskonposizioan agertzen diren predikatuak joskeran berean, zeinek bere argumentua -bat bakarrik-dutelarik, agerrarazirik (Baker 1997, McGinnis 2000).

Hemengo proposamenean buru bat baitagokie aditz kausatiboei, joskeran honelako itxura hartuko dute aditz horiek (Araz deitzen dugu, besterik gabe, kausa burua, $B o z$ burutik bereiz, eta honen pean, dagoena):

\footnotetext{
${ }^{7}$ Alberdik (2002) erakusten du zer ondorio izan duen horrek euskarak mailegatu dituen aditzen erregimenarentzat.
} 


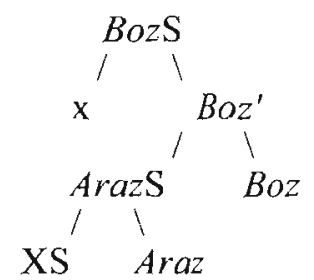

(7)an Araz buruaren osagarria ez da zehaztua, eta kausatibo mota desberdinentzat balio du, erran nahi baitu kausatibo lexikalentzat eta morfologikoentzat.

Euskaraz, dakigun bezala, kausatibo lexikalek eta kausatibo morfologikoek ez dute banaketa bera, erran nahi baitu arazi morfemarekin ager daitezkeen aditz askok ez dute kausazio aldizkatze lexikalik, eta XSk bi kasuetan izaera desberdina izan behar du nahitaez. Zein? Hori da hain zuzen orain aztertuko duguna, kausazio aldizkatze lexikala bereziki ikerturik, hartan agertzen baitira murriztapen handienak. Ikusiko dugu, halaber, Pylkkäneni (2002) jarraikiz, Araz eta Boz buruen arteko erlazioa bereizia dela kausatibo lexikaletan.

\section{Kausazio buruaren osagarria kausatibo lexikaletan}

Ikuspegi deskriptibo bat harturik, kausazio aldizkatze lexikala duten aditzen saila mugatu nahi badugu, orokortze morfosintaktiko hau proposa daiteke: egoera-predikatuez beste aditzek (cf. $\S 1.1,(3 a, b, c)$ ) onartzen dute kausazio morfologikoa. Subjektu ergatiboa duten aditzek, aldiz, ez dute kausatibo lexikalik bideratzen. Hala da subjektu ergatiboa hartzen duten aditz iragankorrentzat (IZEN+egin bezalako aditz lokuzioak barne) lan honen sarreran ikusi dugun bezala, bai eta bazkaldu, dirdiratu, etsi, iraun, ... bezalako aditz deponenteentzat ${ }^{8}$ ere. Ondoko adibideek (non DS datiboa causee edo arazi gisa interpretatzekoa baita) ezintasun horiek agerian ematen dituzte, aditz iragankor arrunt batekin edo objektu zehaztugabea duen batekin (8a), egin aditz arina duen aditz lokuzio batekin (8b), subjektu biziduna (8c) edo bizigabea (8d) duen [+ERG] aditz iragangaitz batekin:

* Pellok Maddiri (ogia) jan dio vs Pellok Maddiri (ogia) janarazi dio

* Pellok Maddiri eztul egin dio vs Pellok Maddiri eztul eginarazi dio

* Pellok semeari bazkaldu dio vs Pellok Maddiri bazkalarazi dio

*Erregeak gerla iraun zuen vs Erregeak gerla iraunarazi zuen

${ }^{8}$ Gogoratzen zaidan salbuespen itxurako kasu bakarra jo aditzarekin agentzen da. Beha ondoko alternantziari:

(i) Ezkilek jo dute

(ii) Ezkilak jo ditugu

Jo iragangaitza (i), zentzu fisikoentzat kitzikagarri diren emisioak adierazten dituen aditza da erabilera horretan; barne kausa duen aditz inergatiboa da Levin \& Rappaport Hovav-en (1995:140) sailkapenen arabera (Perlmutter (1978) eta Perlmutter \& Postal (1984) puntu horretan zuzentzen dituztelarik). Euskaran NORK-aditz gisa agertzen da, dirdiratu eta dangatu bezala. Levin \& Rappaport Hovav-ek (1995:117) diote klase horretako ingeles aditz zenbaitek (adibidez, buzz aditzak) anbiguitate bera izan dezaketela batzuetan, hain zuzen sailkapen bikoitza izan dezaketelako: bame-kausaduna (egitura inergatiboa), edo kanpo-kausaduna (egitura kausatiboetan). Halere, euskaran, jo aditz polisemikoa da eta ez da argi (i)eko crabilera aldizkatze kausatiboari dagokion ala, besterik gabe, objektu zehaztugabea duen aditz iragankorra den; konpara (i)eko adibidea eta (iii)koa:

(iii) Ezkilek mezajo dute 


\section{(8d') *Erregeak gerlari iraun zion vs Erregeak gerlari iraunarazi zion}

Lau adibideetan, ikusten da kausatibo morfologikoa zilegi dela, baina ez kausatibo lexikala. Ergatiboaren agerpena euskaraz kanpoko argumentua dakarren $B o z$ aditz arinaren adierazpena den neurrian, zerbait erraten digu orokortze honek kausatibo lexikaletako kausazio buruaren XS osagarriaz: BozS ezin izan daiteke.

Ikus dezagun, halere, aditz ergatibodunei zegokien hastapeneko orokortze honi eduki zabalagoa eman ez ote dakiokeen. Aditz deponenteak lexikoiko egitura iragankor bati lotuak direla kontsideratuz geroz (Hale \& Keyser 1993, Laka 1993), aditz ergatibodun guztiak gutienetik diadikoak baitira, orokortzea, aditz poliadiko guztietara zabal ez ote daitekeen ikusi behar dugu. Hala izanez, orokortze honen ondorio sintaktikoa garrantzizkoa litzateke, zeren erakustera eman bailezake XS (7)ko errepresentazioan AS soilik izan daitekeela.

Orokortzeak, deskriptiboki bederen, balio duenetz ikusteko, euskaraz, NORNORI aditzak ditugu ikertzekoak, eta haietan bereziki psiko-aditz batzuk ${ }^{9}$ Nahiz guti diren, balia dakizkiguke gure azterketaren aitzinatzeko. Haietan bi aditz mota berezi behar ditugu, alde batetik, esperientzorea datiboan dutenak, eta, esperientzorea absolutiboan dutenak. Lehenbizikoen artean, ahaztu eta gustatu sartuko genituzke, eta bigarrenekoen artean urrikaldu edo errukitu. Oraindik behar bezala ikertu gabe daude euskarazko psiko-aditzak, eta maila deskriptiboan ere, ez dira kontuak oso argi. Ikus dezagun, bada, zer gertatzen den hauekin.

Usaian erabiltzen den aditz horien tipologia (Belletti \& Rizzirena 1988) erreferentziatzat harturik, ahaztu / gustatu psiko-aditzak piacere motako aditzak dira (Artiagoitia 1995, 2000). Aditz horietan, euskaraz, argumentu absolutiboa tema argumentuari dagokio, eta datiboa esperientzoreari. Aditz hauek ez dute onartzen kausazio aldizkatze lexikala, ondoko adibidean ikus daitekeen bezala:

\section{Adinarekin kantuak ahaztu zaizkit}

\section{* Adinak kantuak ahaztu dizkit (vs Adinak kantuak ahatzarazi dizkit)}

Gauza bera gertatzen da esperientzorea absolutiboan duten urrikaldu (aspaldi honetako erabilera) ${ }^{10}$ edo errukitu bezalako NOR-NORI aditzekin. Aditz hauek ere ez dute kausazio aldizkatze lexikala bideratzen: ${ }^{\text {II }}$

\section{Aberatsak bakan urrikaltzen zaizkie behartsuei}

\section{* Apaizaren erranek aberatsak urrikaldu dizkiete behartsuei}

Horko datuak ikusirik, ondoriozta daiteke kausatibo lexikaletan oinarri aditzak argumentu bakarrekoa izan behar duela, eta, [+ERG] ezin izan baitaiteke, NOR-aditza izan behar dela.

${ }^{9}$ NOR-NORI aditzak aditz inergatibo batzuekin ere (ele-aditzekin, adibidez) aurkitzen ditugu, baina kausatibo lexikaletan ez agertzeak ez du gauza handirik adierazten, urrunago ikusiko dugun bezala, datiborik gabe ere ezin ager baitaitezke aditz horiek kausazio aldizkatze honetan. Halaber, datiboarekin ager daitezkeen mugimendu aditzak ere (hurbildu, joan, ...), ez ditut kontuan hartzen hemen.

${ }^{10}$ OEHko datuak ikusiz, inditzen zait 19. mendearen erditsu arte edo, iraun zuela esperientzorea datiboan zuen erregimen zaharrak (errukitu aditzarekin aurkitzen ez dena). Gaur egun ez dut uste inon erabiltzen den salbu literatura hizkuntzan eta horregatik zaharkitutzat jotzen dut. Ondoko bi adibideek aditz horren bi erabilerak erakusten dituzte:

(i) Jainkoari urrikaldu zitzaion gizona (zaharkitua)

(ii) Jainkoa urrikaldu zilzaion gizonari (ez zaharkitua)

Adibide bat aurkitzen da OEHan, errukitu psiko-aditz kausatibo gisa erabilia izanik : famili gajo orrek errukitzen nau (Soroa, Baratzan, 54). Ez dakit erabilera hedatu bati dagokion. 
Erran ote daiteke, orduan, egoera aditzez kanpoko (cf. 1.1) NOR-aditz guztiak aurki daitezkeela kausa-buruaren (Araz) osagarri gisa? Orain ikusiko dugun bezala, ez. NOR-aditzetan ere aditz klase batzuk badira, kausazio morfologikoa onarturik ere, kausazio lexikala baztertzen dutenak. Hona egin daitekeen sailkapena:

(10) Kausazio aldizkatze lexikala eta NOR-aditz klase nagusiak: ${ }^{12}$

Aditz erreflexiboak (garbitu, jantzi, orraztatu, ...)

Jarduera-aditzak (jokatu, , jostatu, mintzatu, ...)

Gertatze aditzak (gertatu, jazo, ...)

Egoera-aldaketa aditzak (hil, hautsi, zabaldu, ...)

Toki-aldaketa aditzak (atera, hurbildu, joan, ...)

BAI

Psiko-kausatiboak (aspertu, harritu, izutu, poztu, ...)

BAI

(10)ean agerrarazi dugu zein diren aldizkatze kausatiboa onartzen ez duten NOR-aditz motak. Laburzki, adibide batzuen bidez, kausatibo lexikal agramatikal horien zenbait adibide ematen ditugu.

\section{Kausazio aldizkatzea ez duten NOR-aditzak}

Bederazka ikus ditzagun (10)eko taulan EZ dakarten aditz-klaseak.

\subsection{NOR-aditz erreflexiboak}

Euskaraz aditz iragankorren forma erreflexiboak bi modutara agertzen zaizkigu: edo izenorde erreflexibo bat erabiliz aditzaren egitura iragankorra kanbiatu gabe, edo joskeran aditza argumentu bakarrekoa eginez, hura absolutiboan izanik (Ortiz de Urbina 1989). Aditz gehienentzat erabide estandarra forma iragankorra begiratzen duena da, baina beste zenbait aditz badira non lexikalizatu baita erabide iragangaitza. Halakoak dira, adibidez, beztitu edo orraztatu aditzak. Orain beha ondoko adibideei:

(11a) Pello beztitu da

(1 ib) Maddik Pello beztitu du

(1 lc) Pello orraztatu da

(11d) Maddik Pello orraztatu du

Ikus daitekeenaz, (11)ko aditzek erabilera iragangaitza eta iragankorra badituzte. Haatik, ez dute kausazio aldizkatze lexikala erakusten, (1lb,d) adibideek ez baitituzte (11 a,c)koak barneratzen. Izan ere, (1 la,c)ko adibideetan aditza erreflexiboa da, eta Pellok bere burua beztitzen eta orraztatzen duela

${ }^{12}$ Kanpoan uzten ditut, alde batetik, lehen erran bezala (1. oh.), egoera-aditzak, eta bestetik aspektu-aditzak (bukatu, hasi, ...). Azken hauek direla eta, ikus ditzagun ondoko adibideak :

(i) Pilota partida hasi / bukatuzen

(ii) Pilotariek partida hasi / bukatu zuten

Dudarik batere gabe, kontsidera daiteke (i) eta (ii)ko adibideek aldizkatze kausatiboa adierazten dutela (Pustejovsky 1995:201). Halere, aldizkatze honek azterketa berezia behar du, aldizkatzea kasu honetan aspektu aditzek izan ditzaketen perpaus osagarriei lotua baita. Aspektu aditzak kontrol perpaus jokatu gabe batekin edo, koertzioaren bidez, izen batekin agertzen dira:

(iii) Maddi liburuaren irakurtzen hasi zen

(iv) Maddik liburua hasi zuen

(iv)ren interpretazioak nahitaez eskatzen du ebento-predikatu bat, liburua objektutzat har dezakeena, adibidez, testuinguru bereizirik ez bada, irakurri edo, Maddi idazle bada, idatzi. Ohargarria da, haatik, liburu bezalako izen bat ez baita ebento-izena, ez dela aspektu aditzaren subjektua izaten ahal:

(v) ${ }^{*}$ Liburua hasi zen (vs Pilota partida / Gerla / Filma ... hasi zen). 
ulertzen dugu; ( $11 \mathrm{~b}, \mathrm{~d})$ ko adibideetan, aitzitik, Pellok ez du bere burua beztitzen edo orraztatzen. Aditz erreflexiboekin erabilera kausatibo baten erdiesteko nahitaezkoa da kausatibo morfologikoaren baliatzea: Maddik Pello beztiarazi / orraztarazi du. Aditz horiek iragangaiztasun eratorria dute eta dagokien lexikoi deskonposizioan bi argumentu dituzte, bat barnekoa eta bestea kanpokoa, erreferentziakide direnak (Reinhart \& Siloni, bidean). Funtsean, beraz, hemengo ezintasuna, aditz iragankorretan kausitzen dena da.

\subsection{NOR-aditz inergatiboak}

Orokortze hau proposatzen du Levinek (1983, 1989) euskal aditzez egiten duen sailkapenean: NOR-aditzak aditz inakusatiboak dira (mintzatu aditza salbuespen bakarra izanki). Nahiz badirudien NOR-aditz inergatiboak gero eta gehiago NORK-aditz gisa erabiltzeko joera zabalduz doan, Hegoaldean bereziki (Sarasola 1977), ${ }^{13}$ orokortze hau gehiegizkoa da (Oyharçabal 1993, Etxepare bidean). Hots, aditz inergatibo andana bat bada, Iparraldeko erabileran bereziki, semantikoki argi eta garbi inergatiboak izanik, mintzalmoldeen arabera NORaditz gisa balia daitezkeenak: (zerbaitetan) ari izan, bazkaldu, behatu, borrokatu, dantzatu, elekatu, entseiatu, jauzi, jazarri, jokatu, jostatu, mendekatu, mintzatu, ... Aditz horiek aditz agentiboak dira. Aditz klase hau da, hain zuzen, inakusatibitateari buruzko ikerlanetan, orok (ikus, adibidez, Perlmutter \& Postal 1984, Levin \& Rappaport Hovav 1995:136) aditz inergatibotzat jotzen dituztenak ; (halere, aldaketa noratua duten toki-aldaketa aditzak, agentiboak izan daitezkeen arren, ez dira klase horretan sartzen, geroago oroitarazten dugun bezala, cf. §5.2.).

Ondoko adibideek erakusten duten bezala, NOR-aditz inergatiboek ez dute kausatibo lexikalik bideratzen (12b, 13b):

(12a) Pello kanpoan jostatu da

(12b) *Maddik Pello kanpoan jostatu du (vs Maddik Pello kanpoan jostararazi du)

(13a) Nire aurka borrokatuko zara

(13b) *Buruzagi berriek nire aurka borrokatu zaituzte (vs Buruzagi berriek nire aurka borrokarazi zaituzte)

Borrokatu aditza iragankorki ere erabiltzen ahal dute anitz hiztunek, ondoko adibidean bezala:

\section{(13c) Buruzagi berriek zu ere borrokatu zaituzte}

Erabilera iragankor horretan, haatik, ez dugu erabide kausatiborik eta (13c) ezin interpreta daiteke $(13 \mathrm{~b})$ bezala. $^{14}$

13 De Rijken arabera (2002), ordea, Levinen hipotesiak euskara zaharraren (16. mendearen hastapenerainokoa) egoera deskribatzen du. Ikusmolde horretan, gaur egun inergatiboak diren NOR-aditzak, bietarik bat: edo semantikoki inakusatiboak izan ziren iraganean (adibidez, trabaillatu aditza nekatu aditzaren parekide semantikoa izanik) edo aditz iragankorrak izan ziren erabide antipasiboaren ondorioz hartu dute NOR-aditzen forma (adibide\%, mendekatu, mintzatu). Puntu hau ez dut ertabaidatuko hemen.

14 Zenbait euskalkitan borrokatu [+ERG] da erabilera iragangaitzean. Aski berria da, irudiz, Hegoaldean zabalduz doan erabilera hau (OEHan ez da agertzen). Zehaztu gabeko objektua duen aditz gisa aztertzekoa bide da orduan forma hau, ez aditz inergatibo huts gisa (hauek, ikusi dugun bezala, ez baitute kausazio aldizkatzerik). 
Gauza bertsua gertatzen da elezko komunikazioa adierazten duten elekatu, hizkatu, mintzatu, solastatu bezalako aditzekin. Erabilera iragankorra badute (Iparraldeko euskalkietan, bederen), ondoko adibideetan ikus daitekeen bezala:

(14a) Pello mintzatu da

(14b) Maddik Pello eta Jakes mintzatu ditu

Ordea, (14b) adibideak ere, hartako aditza iragankorra izanagatik, ez du adiera kausatiboa (Pello eta Jakes komunikazio-kide dira, ez mintzatzaile). Kontrastea agerian emateko, aski da adizlagun baten sartzea Pello mintzatzaile gisa interpretatzera bortxatzen duena:

(14c) Pello bere buruarekin mintzatu da

\section{(14d) *Maddik Pello bere buruarekin mintzatu du}

(14d) adibidea gaizki eratua da, zeren izan dezakeen interpretazio bakarrean ((14c)ri dagokiona) solas aditz bat (inergatibo bat, beraz) oinarritzat daukan kausatiboa baita.

Ez da argi aditz horien kasu morfologia nola azaldu behar litzatekeen. Hemen aldezten den lexikoi deskonposizioan nekez kokagune desberdinak emanen dizkiegu ondoko pareetako aditzen argumentuei: borroka egin [+ERG] eta borrokatu [-ERG]; ele egin [+ERG] eta elekatu [-ERG]; hitz egin eta hizketatu [-ERG]; zintz egin [+ERG] eta zintzatu [-ERG]; ...(Oyharçabal 1993). Franko erregularra da aldizkatze hori inkorporazio aditz batzuekin, adibidez solas aditzekin. Aditzaren oinarrian den izena (ele, hitz, solas) zerekin bateratzen den: edo egin aditz arinarekin, edo morfologikoki hutsa den aditz buru batekin forma soiletan (Hale \& Keyser 1993).

Menturaz, Marantzen (1991) azterbideari jarraikiz, euskal ergatiboa kasu dependente gisa harturik, haren agerpena objektu posizioaren ikusgaitasunari lotua dela kontsidera daiteke (Oyharçabal 1994). Gisa horretan, nola aditz arinarekilako lokuzioetan beti ikusgai baita objektua, ergatiboaren erabilera nahitaezkoa da. Aditz burua zero formakoa duten inkorporazioetan, aldiz, objektu posizioa hustua da, ezin-ikusizkoa geratzen delarik. Ezin-ikusizkotasun horrek, ondorioz, kasu dependentearen (ergatiboa) agerpena eragozten du, honek, agertzeko, lehenik objektua 'ikusi' behar baitu. Aztermolde honetan, NORK-aditzen saila salbuespen gisa agertzen da, haien kasuan objektu inkorporatua ikusgai gelditzen baita.

Dena den, oso adierazgarria da NOR-aditz horien azterketarako, sekula ezin ager daitezkeela kausatibo lexikaletan, alta haietarik batzuek, gorago ikusi bezala (11e, 12b), erabide iragankorra onartzen dutelarik. Horrek indar ematen dio haien argumentua kanpoko posizio batean dagoela dioen aztermoldeari.

\subsection{Gertatze aditzak}

Gertatze NOR-aditzei ere ez dagokie era kausatiborik. ${ }^{15}$

(15a) Nire otoitzen ondotik, bi mirakuilu gertatu dira

(15b) *Nire otoitzek bi mirakuilu gertatu dituste

Aurrekoetan ez bezala hemen argumentu bakarra ez daiteke kanpoko argumentutzat har, gertatze aditzak aditz inakusatiboak baitira. Beraz, ezin erran

${ }^{15}$ OEHan bizpahiru adibide badira gertatu iragankorrean dutenak eta irudiz kontradibide direnak ('hacer que resulte, hazer que sea' itzultzen da hiztegian). Ez dut uste orokortzea kanbiatzeko modukoak direla. 
daiteke horregatik gertatzen dela $(24 b)$ ko ezintasuna. Bestalde, euskara ez da bakarrik ibilki modu horretan, datu berak baititugu ingelesez (Levin 1993:21) eta frantsesez ere:

(16a) Il est survenu / advenu un miracle

(16b) * Mes prières ont advenu/survenu un miracle

Survenir eta advenir aditzak frantses gertatze-aditzak dira. (16a)n ikusten dugu aditz horiek, aditz inakusatiboekin bakarrik aurkitzen den itzuli batean erabil daitezkeela, subjektu zehaztugabea aditzaren ondotik agertuz. (16b) adibideak frogatzen du aditz inakusatibo horiek kausatibo lexikal batean ezin ager daitezkeela.

Geroxeago proposatuko dugun deskonposizio lexikalean, kausazio lexikala aldaketa-predikatuari lotuko diogu. Gertatze aditzetan, ordea, existentzia predikatua dugu eta ez aldaketa adieraz dezakeen predikatua. Xehetasun gehiagotan sartu gabe, diferentzia horren bidez azalduko dugu aditz horiekin agertzen den kausatibo lexikalik eza.

Ikus daitekeenaz, NOR-aditz klase batzuk ez dira kausatibo lexikalekin aldizkatzen. Ikus ditzagun aukera hau eskaintzen dutenak.

\section{Kausazio aldizkatzea duten NOR-aditzak}

Aldaketa aditzetan bi azpisail bereizteko dira: egoera-aldaketa aditzak $(\$ 5.1)$ eta toki-aldaketa aditzak ( $\$ 5.2)$. Psiko-kausatiboak, azkenean haiek ere aldaketa aditz gisa azterkatzea proposatuko dugun arren, bereiz ikertuko ditugu ( $\$ 5.3)$.

\section{I. Egoera-aldaketa aditzak}

Egoera-aldaketa aditzetan, hurbileko barne-argumentuaren itxuran edo izaera fisikoan aldaketa adierazten duten aditzak sartzen dira eta bereziki izenondo (edo izen) batetik eratorriak direnak: arraildu, belztu, berotu, edertu, eritu, hautsi, hil, hoztu, idortu, loditu, luzatu, urtu, zabaldu, ... Aditz horiekin kausatibo lexikalak guztiz emankorrak dira.

\section{(17a) Udaberriarekin bazterrak laster berdatu ziren \\ (17b) Udaberriak bazterrak laster berdatu zituen}

Gure hastapeneko atzerbideari jarraikiz, gisa horretako kausatiboei dagokien errepresentazioa bikoitza izan daiteke, izenondo edo izen batetik eratorriak ote diren. Lehenbiziko kasuan (18) errepresentazioa dugu: ${ }^{16}$

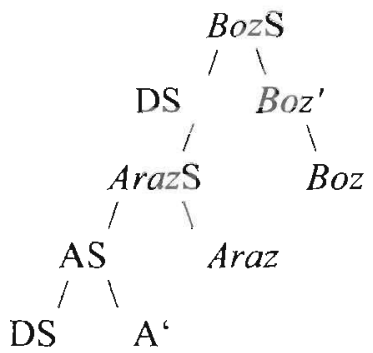

16 Badaiteke PospS batetik ere sor daitekeela eratorketa, posposizioa Ø izanik. Psikokausatibn ntzat bereziki atxikiko dugu azterbide hau (cf. infra (49)), baina badirudi hauetaz kanpo ere aurkitzen dela : loretu, larrutu, ... eta, beharbada, puskatze aditzetan: zatitu, apurtu, xehatu, etab. Ikus adibidez, gisa horretan, Azkarate M., Odriozola J.C., Perez E., \& Zabala I. [hemendik aitzina AOPZ] (2000). 


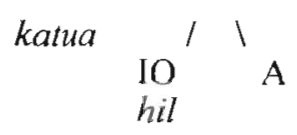

Aditz iragangaitzetan inakusatiboak eta inergatiboak elkarretarik bereizteko Levin \& Rappaport Hovavek (1995:91) irizpide nagusi bat kontuan hartzen dute: egoera-aldaketa aditz gehienak kanpo kausa dutenak izanki, aditz inakusatiboak ohi dira, eta, alderantziz, barne kausa duten aditzak aditz inergatiboak. Azken puntu honek, ordea, salbuespena badu: badira egoeraaldaketa aditz batzuk, berezko barne-kausa dutenak direnak (Levin \& Rappaport Hovav 1995:159). Aditz horiek barne kausa duten neurrian, nekez kausatibo lexikaletan ager daitezke. Alabaina, baldin barneko kausa batek sorrarazten badu egoera aldaketa, kausatibo lexikaleko subjektua, kanpo kausa adierazten duena, ezin izan daiteke zuzeneko kausa (gogora $(5 a, b)$, eta beraz horrelako aditzek aldizkatze kausatiborik ezin izan dezakete.

Bizkitartean, Levin \& Rappaport Hovavek (1995:99) azpimarratzen duten bezala, hizkuntza guztiek ez dute berdin trinkatzen auzi hau, eta hizkuntza bereko hiztunen artean ere gorabeherak eta aurkakotasunak ez dira falta. Gure hemengo lana deskriptiboa izanik gehienik, saiatuko gara euskal aditzetan zer gertatzen den ikustera.

Lehenik, joera bezala, badirudi, euskarak aski aise onartzen duela aldizkatze kausatiboa, kontzeptualki barne-kausadun aditz gisa kontsidera daitezkeen egoera-aldaketa aditzekin. Izan ere, badira euskal aditzak aldizkatze kausatiboa dutenak, ondoko erdaretan, barne-kausadunak izanik, kausatibo lexikaletan nekez agertzen direnak.

Gaztelerazko egoera-aldaketa aditzak ikertuz, Mendikoetxeak (1999:1599) seinalatzen du barne-kausadun egoera-aldaketa aditzetan anitz kanpo-kausadun gisa ere ager daitezkeela, nolako argumentua duten. Haren arabera, aditza animaliez eta fenomeno naturalez mintzatuz erabil badaiteke, aise agertuko da barne-kausari dagokion interpretazioa, subjektu bizigabe batekin aurkituko ez dena, ondoko adibideak erakusten duten bezala; cf. Mendikoetxea (1999:1599):

(19a) Juan ha ensachado (barne kausa)

(19b) La carretera se ensancha en el km 5 (kanpo kausa)

Euskaran, irudi luke gai inerteei edo bizigabeei dagokien prozesuak direlarik (landareak ez ditut hauetan sartzen), hiztun guztientzat posible dela kausatibo lexikalen erabiltzea. ${ }^{17}$ Urtzea, usteltzea, herdoiltzea, ... bizigabeko gaiei gerta dakizkiekeen aldaketak dira, kontzeptualki barne-kausa batek eragiten dituela kontsidera baitaiteke. Euskaraz, ordea, kanpo-kausadun gisa agertzen zaizkigu eta aldizkatze kausatiboa badute. Horrela, frantsesez fondre aditza nekez, agertuko da erabilera kausatiboan, baina aise euskaraz urtu aditza:

(20a) *Le soleil a fondu le verglas (vs Le soleil a fait fondre le verglas)

(20b) Eguzkiak bideko horma urtu du

Aldaketa bizidun bati gertatzen zaiolarik, hiztun guztiek ez dituzte intuizio berak, eta anitzetan epaiak zalantzarekin emanak dira. Adibidez, ikus ditzagun

17 Fenomeno atmosferikoak adierazten dituzten aditzak (argitu, atertu, ...) bereziak dira. Aldizkatze kausatiboa onartzen dute, baina gehienetan eguraldi aditzekin ohikoa den sasiargumentu batekin:

(i) euria atertu da

(ii) euria atertu du 
aldizkatzeak frantsesez eta euskaraz, subjektu biziduna duten grossir / loditu eta maigrir / mehatu bezalako aditzekin: ${ }^{18}$

(21a) Pierre a grossi / maigri

(21b) *Les médicaments ont grossi/maigri Pierre

(22a) Pello loditu/mehatu da

(22b) \%Erremedioek Pello loditu / mehatu dute

Adibide horretan, non aditzek temaren egoera fisikoan aldaketa bat seinalatzen baitute, euskal hiztun zenbaitek, ez denek haatik, ${ }^{19}$ onartzen dute frantsesez nekez egin daitekeen aldizkatze kausatiboa. Hala gertatzen da, itxura guztien arabera, gorritu aditzarekin ere, jendeari, ahalketzen delarik, aurpegian gertatzen zaionaren adierazteko erabilia denean. Ikus ondoko adibideak euskararekin batean inguruko zenbait hizkuntza aipatzen dituztenak: ${ }^{20}$

(23a) Peter blushed

(23b) *The compliment blushed Peter (Levin \& Rappaport Hovav 1995:91, 160)

(24a) Maria enrojeció

(24b) *La enhorabuena enrojeció a Maria (Mendikoetxeak 1999:1604),

(25a) Marie rougit

(25b) *Vos paroles rougirent Marie (Labelle 1990:306),

(26a) Maddi gorritu zen

(26b) \%Zuk esandakoak gorritu egin nau ${ }^{21}$

Landareek dutelarik jasaten aldaketa, piska bat gauza bera gertatzen da. Hiztun guztiek ez dute berdin egiten. Adibidez, zenbaitek onartzen dute loratu edo lilitu aldizkatze kausatiboan agertzea, besteek ez: ${ }^{22}$

18 Gaztelerako kontuak ez dira hain argi. Mendikoetxearen arabera, barne-kausaren aldeko azterketa nagusitzen da egoera aldaketa horietan :

(i) Pedro adelgazó

(ii) *Un nuevo medicamento adelgazó a Pedro (Mendikoetxea 1999:1598)

Molinerren hiztegiak ere erabilera iragangaitza baizik ez du seinalatzen. Halere, Gaztelera Frantsesa Larousse hiztegiaren arabera behintzat erabilera kausatiboa ere aurkitzen da adelgazar sarreran:

(iii) Esta medicina te adelgazarà

OEHan adibide batzuk agertzen dira, bai Iparraldean, bai Hegoaldean, garai desberdinetan: Janhari irintsuek loditzen dute (Harriet); Etxeko jatekiak lorittu eiñ nau (T. Etxebarria); Ene beheraspenak eta ene ahuenak halako fazoinez mehatu naute (Gasteluçar, Egia katolikak, 47). Zenbait hiztunek gizendu nahiago baitute erabili horrelako kontestuetan, ez dirudi funtsezko aldaketarik baden orduan haientzat.

${ }^{20}$ Irakurlea ohartu bide den bezala adibideetan arazle agentiborik ez dut ematen. Badirudi horrek ere bere eragina duela hemengo epaietan (arazlea instrumentua izanik adibideak onarrerrazagoak izanik). Mementoan, puntu hau, arazleak zuzeneko kausaren adierazteko beharrari lotuko diot.

21 Inkestetan iruditu zait aditzaren hanpadurak laguntzen zuela onespena (halere, Zuk erranak gorritu nau, besterik gabe onartu didate hiztun batzuek). Horregatik ematen dut adibidea forma horretan. Seinala dezadan, OEHan agertzen dela erabide kausatiboa gorritu aditzarekin. Argiago izateagatik hemen egokitzen dudan J. A. Irazustaren (Bizia garratza da, 24) adibide horrek honela dio : Euli batek gorritzen du Miren (testua ongi interpretatzen badut, Miren guztiz herabe edo lotsati dela adierazteko). 


\section{\%Maiatzeko eguzkiak gereziondoak loratu ditu}

Itxura guztien arabera, beraz, oso guti dira euskaraz hiztun guztientzat, egoera-aldaketa aditz inakusatiboak, erabilera kausatiboa ezin izan dezaketenak. Hazi aditza (landareez mintzatuz erabilirik) hiztun askorentzat aldizkatzerik gabekoa bada, beste batzuentzat kausatibo gisa ere erabil daiteke, subjektua agentiboa denean bederen: ${ }^{23}$

(28a) Gure etxe inguruan landareak behar bezala hazi dira aurten

\section{$\%$ Baratzezainak landareak hazten ditu \\ (28c) *Eguraldi onak/ongarriak gure landareak ongi haziko ditu}

Beste fenomeno bat ere kausitzen da hemen aipatzen dugun aditz sailarekin. Landareei eta animaliei dagozkien zenbait parte adieratzen duten izenetarik sortu aditz batzuk kausazio aldizkatze berezian agertzen dira: aletu, bihitu, kimatu, lumatu, ... AOPZek (2000:439) seinalatzen du fenomeno hau, non aditzak, erabilera inakusatiboan, berezko barne kausadun aditzak baitira eta erabilera kausatiboan, berriz, izen inkorporatuak denotatzen duen partearen kentzea ere adierazten baitute:

\section{Kardua kimatu da}

\section{Jendeek mahastia kimatu zuten}

Euskaraz kausatibo lexikalak, orain arte ikusi dugun bezala, franko erregularrak dira, erran nahi baitu lexikalizazioari datxekion idiosinkretismo guti aurkitzen dela. Hau, ordea, gisa horretakoa da.

\subsection{Toki-aldaketa aditzak}

Toki-aldaketa aditzetan ez dira higimodua aditzean berean adierazten duten aditzak, bai ordea norabidea berez agertzen dutenak. ${ }^{24}$ Lehenago ikusi baitugu aditz monadiko agentiboak aditz inergatiboak ohi direla, orokortze horri buruzko salbuespen garbia osatzen dute aditz horiek, Levin eta Rappaportek (1995) seinalatu eta arautu bezala. ${ }^{25}$ Izan ere aditz horietarik anitzen argumentua agentiboa izanagatik, inakusatiboak dira eta kausazio aldizkatzea badute:

22 Nahiz testuinguru oso berezia den, seinala dezadan, bihitu aditza agertzen dela erabilera kausatiboan Barbierren ipuin batean (Ipuinak, 57), arazlea biziduna izanik: Jesusek suarekin ogiak bihitu zituen (Jesusen ahal bereziei esker metatuak izan ziren ogiei su eman izan zitzaien eta bihitu ziren). Ingelesez, barne-kausadun gisa ager daitezkeen aditzen erabilera kausatiboa euskaran baino murritzago da itxura guztien arabera. Halere, Levin \& Rappaportek (1995:99) diotenaz, hizkuntza hartan ere hiztunen arabera erabilera bikoitz hori izan dezaketen zenbait aditz badira.

23 Abereez (edo jendeez) mintzatuz ez da arazorik, baina kontuak nahasiago dira orduan, aditzak beste erran nahi bat(zuk) bait(it)u.

24 Euskaraz, egia erran, ez da aditzaren barnean zehazten mugimenduaren manera, baina konposizionalki: igeri egin, igerika ibili; hegan egin, hegalka ibili; laster egin, lasterka ibili; oinez joan / etorri / ibili ... Hots, mugimendu aditzetan jarduera aditzetan gertatzen dena (lan egin, lanean ibili; irri egin, irriz ari izan, ...) aurkitzen dugu. Levin \& Rappaporten (1995:147) arabera, toki-aldaketa aditzak aspektualki achievement aditzak dira, eta nolabait mugimendu noratua adierazi behar dute bururapena beren baitan izateko. Euskaran, ordea, ez da argi murriztapen handiegi ez ote den, ibili aditza, irizpide honen arabera, ez bailitzateke tokialdaketa aditza (ez baitu norabiderik zehazten). Egia da ibili aditza jarduera aditz gisa ere agertzen dela lokuzio batzuetan: lanean / pilotan / gezurretan ... ibili.

25 Ikus Levin \& Rappaport Hovavek (1995:144) formulatzen duten Aldaketa Noratuaren Lotura Araua (Directed Change Linking Rule), honal baitio arau hortek: Demagun aditz bat aldaketa noratua deskribatzen duena. Zein argumentu baitagokio aldaketa noratua jasaten duen izakiari, hura aditz horren hurbileko barne argumentua da (direct internal argument). 
(30a) Kanpora atera zara

(30b) Kanpora atera zaitut

(31a) Haurrak oheratu dira

(31b) Haurrak oheratu ditut

Egoera-aldaketa aditzetan, ikusi dugu arras guti direla kausazio aldizkatzea osoki eta hiztun guztientzat ezinezkoa zutenak. Gehiago dira horrelako kasuak toki-aldaketa aditzetan:

- Kausatibo lexikala dutenak: ${ }^{26}$ agertu, amildu, atera, elkarretaratu, etxeratu, goititu, hurbildu, igan, ilki, jaitsi, jalgi, \%joan, sortu, urrundu, $\ldots$

- Kausatibo lexikala onartzen ez dutenak: ailegatu, arribatu, erori, etorri, irten, jaio, jin, \%joan, partitu, ...

Zaila da modu argian ikustea zerk duen sortzen bereizkuntza hau. Badirudi aldizkatzerik gabekoak direla markatuak. Gutiago dira eta zerrenda mugatua dute. Adizkatzea dutenetan sartzen dira adberbio batetik edo posposiziodun forma batetik eratorriak diren aditzak, -ra posposizioa dutenak bereziki (goratu, etxeratu, lurreratu, ...), birtualki bederen beti sor daitezkeenak.

Zenbait aditzekin, joan aditzarekin adibidez, erabilera kausatiboa euskalki batzuetan kausitzen da, baina ez besteetan (ikus OEH):

Ardiak mendira joan ziren

$\%$ Artzainak ardiak mendira joan zituen

Toki-aldaketa aditz horien errepresentazioa, kasu honetan ere aditz eratorri batekin erakutsirik, honela agertzen zaigu:

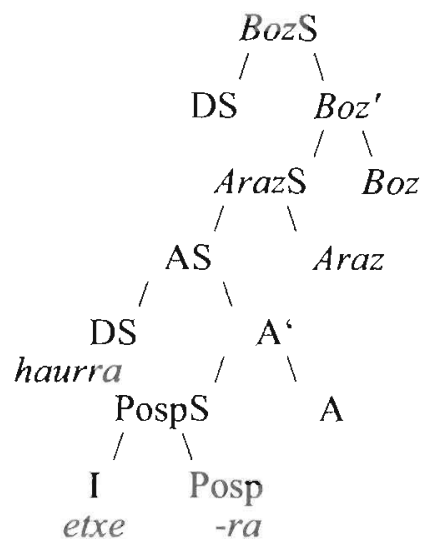

PospS egitura ageri da norabidea adlatiboaren bidez adierazia denean, edo urrun edo hurbil bezalako adberbioak erabiliak direnean. Gaineratikoetan, norabidea aditzaren beraren berezko edukiari dagokio (jautsi, igan, ...) eta erroa da orduan aditzaren osagarria (Marantz 1997). ${ }^{27}$

${ }^{26}$ Agertu toki-aldaketa aditz gisa tratatzen dut. Kasu adlatiboa eskatzen du: plazara agertu. Berdin egiten dut jaio aditzarentzat.

${ }^{27}$ Hemen jarraikitzen zaion morfologia banatuaren azterbidean, erroak ez du aditz kategoriazko tasunik ekartzen, A burura igatean harizen du morfemak tasun hori. 


\subsection{Psiko-aditz kausatiboak ${ }^{28}$}

Sail honetan, euskaraz NORK-NOR aditz gisa agertzen zaizkigun psikoaditzak sartzen dira: alaitu, aspertu, enoatu, harritu, izutu, liluratu, poztu, ... Literaturan ez dira beti aditz kausatibotzat hartuak izan. Alabaina, subjektua, haietan, tema argumentu gisa agertzen da, beste batzuetan argumentu bera objektu gisa agertzen delarik. Beha ondoko adibideei:

(35a) Peter fears bears

\section{(35b) Bears frighten Peter}

Kontsideratua izan da literaturan bi perpaus horietan Peter DSak theta-errola bera duela (esperientzorea) eta bears DSak ere bai (tema). Bizkitartean, sintaktikoki gauzak bestela agertzen dira: tema argumentua, adibide batean (35a) objektua da, eta bestean (35b) subjektua ; eta esperientzore argumentua, adibide batean (35a), objektua da, eta bestean (35b) subjektua. Egoera hau guztiz paradoxikoa da, theta-erlazioak joskera erlazioetan aurkitzen direla onartzen bada behintzat (cf. Bakerren Uniformity Theta Assignment Hypothesis, 1988:46). Paradoxa honetarik ateratzeko Belletti \& Rizzik (1988) aditz inakusatiboen azterketa aplikatzen diete psiko-aditz kausatiboei. Haien proposamenean subjektu gisa agertzen den tema argumentua D-egituran aditzaren hurbileko barne argumentua da, eta esperientzoreak, ASaren barnean, tema baino goragoko posizio batean izanik, kasu akusatibo inherentea hartzen du. Nola kanpo argumenturik ez baita, subjektuaren gunera igaten da tema argumentua, hala nola gertatzen baita aditz inakusatiboekin. Beraz, tema argumentua subjektu deribatua da, (36)an ikus daitekeen bezala:

$$
\operatorname{Tema}_{1}\left[v \mathrm{vP}\left[v \cdot \mathrm{t}_{1}\right] \text { Esperientzorea }\right]
$$

Belleti \& Rizzik (1988) argumentu sintaktiko indartsuak emanik ere azalbide honen alde (erran nahi baitu preoccupare - frighten klaseko subjektua deribatua delako hipotesiaren alde), beste zenbait autorek baztertu dute azterbide honen oinarrian den azterketa tematikoa (Dowty 1991, Pesetsky 1995, Tenny 1995, Baker 1997). ${ }^{29}$ Pesetskyk (1995) bereziki oharrarazten du the article DSren theta-errola doi bat desberdin zela ondoko bi adibideetan:

\section{(37a) John is angry at the article}

\section{(37b) The article angered John}

Pesetskyk (1995:56) azpimarratzen du (37a)n the article emozio jomuga (target of emotion) dela, eta $(37 \mathrm{~b}) \mathrm{n}$, berriz, emozio arazlea (causer of emotion). (37a)n artikulua da Johnen haserrea zuzendua den gaia ; (37b)n, berriz, artikuluaren haserrearen kausa da, baina ez da baitezpada hari buruz zuzendua Johnen haserrea. Johnentzat menturaz ongi egina da artikulua, eta hartan

28 Deitura desberdinak aurkitzen dira literaturan, anitzetan italierazko (preoccupare) edo ingelezko (frighten) aditz bat paradigma-ikur gisa baliatzen delarik. Hemen erabiltzen duguna Grimshawek (1990) darabilen psychological causative deiturari darraio. Pesetskyk (1995) EspObj aditzak ere deitzen ditu.

${ }^{29}$ Grimshawen $(1990: 32,36)$ jarrera artekoa da. Onartzen du Belleti \& Rizziren (1988) azterketa tematikoa (subjektua tema izanik) baina aspektualki argumentu hura bera da aitzindaria (the aspectually most prominent argument), eta, beraz, haren teorian, subjektua aditz horietan ez da deribatua. Grimshawentzat frighten klaseko aditzak ez dira aldizkatze kausatiboan sartzen, subjektua ez baita kanpoko argumentua. Azpimarratzen du ingelesez forma iragangaitza ez dela agertzen aditz horiekin:

(i) *John frightened

Erran behar da, haatik, klase horretako aditzak euskaraz arazorik gabe erabil daitezkeela modu horretan : Pello izutu zen. 
kontatzen den gauza batek haserre jartzen du. Pesetskyren azterbideari jarraikirik, engainagarria da psiko-aditz horietan Beiletti \& Rizzik (1988) egiten duten azterketa tematikoa, zeren forma iragankorretan subjektua arazlea baita, hala nola proposatua izan baitute beste zenbait autorek ere (Dowty 1991, Baker 1997, eta, euskararen azterketan, Zabala 1993:203). Guk ere hemen ikusmolde hau guretuko dugu .

Beha dezagun, beraz, nola agertzen diren psiko-aditz kausatiboak euskaraz. (39)an ematen ditugu adibide batzuk:

\section{(39a) Maddi enoatu / harritu / izutu / kezkatu / poztu da \\ (39b) Pellok Maddi enoatu / harritu / izutu / kezkatu / poztu du}

Horrelako pareei azterbide kausatiboaren aplikatzeko zailtasuna uztarduratik bereziki heldu dira. Alabaina, Artiagoitiak (2000:110) seinalatzen duen bezala, psiko-aditz kausatiboekin usaiaz kanpoko uztardura loturak kausi daitezke. Kontsidera ondoko adibideak:

(40a) Nire buruak izutzen nau (cf. nazkatu aditzarekin Artiagoitia 2000:110)

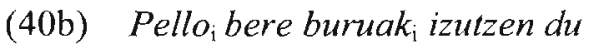

Adibide horietan ikus daitekeenaz, psiko-kausatiboetan Xen burua esapide erreflexiboa subjektua da, eta objektua da haren uztartzailea. Bi arazo sortzen dizkigute (40)ko datuek. Lehena, esapide erreferentziadunak perpausean libre izan dehar direla dioen $\mathrm{C}$ Hatsarreari dagokio, eta bigarrena, esapide anaforikoek dagokien eremuan uztartuak izan behar dutela dioen A hatsarreari.

Lehenbiziko arazoa ikus dezagun. (40b)n, objektua (Pello) esapide erreferentziaduna da eta bizkitartean perpausean berean uztartua da subjektuak c-komandatzen baitu. Bere burua eta Pello indizekideak badira C Hatsarrea, dudarik batere gabe, bortxatua da, hala nola (41)ean ere egina baita; ikus Belletti \& Rizzi (1988):

\section{*Himself $f_{\mathrm{i}}$ worries Peter}

(41)ean Peter bezala, (40b)n Pello erreferentziadun espresioa da, eta irudi luke subjektuak (40b)n ere uztartzen duela. Hortaz, segurtatu behar dugu lehenik (40)ko adibideetan subjektua eta objektua indizekideak direla. Perpaus horiek hurbilagotik ikertzen direnean, gauzak ez dira hain argi. Adibidez, anaforiko erreziprokoari behatzen badiogu, ohartzen gara (40)ko aukera guztiz agramatikala dela, (42)an ikusten den bezala:

\section{* Lagunak elkarrek izutzen ditu}

Ikus dezakegunaz, psiko-kausatiboetan elkar izenordea ezin erabil daiteke subjektu posizioan, bere burua egin daitekcelarik. Nola esplika diferentzia hori, ondoko adibide parean aurkitzen ez duguna?

\section{Lagunek elkar hilen dute}

(43b) Lagunek beren burua hilen dute

Badaiteke (40)ko aukera Xen burua forma anaforikoaren berezko barne egiturari esker sortua izatea. Ohargarria da, alabaina, bere burua sintagmak morfologia konplexua duela eta DS arrunt bat bezala agertzen dela, buru lexikal gisa gorputz parte bat (buru) izendatzen duen izen bat izanik. Kontsideratuko dut (43b)n Xen burua anafora metonimikoa izanik (Safir 1996), hartan $*_{\mathrm{i} / \mathrm{i}}$ 
irazkia indargabetua dela ${ }^{30}$ (Rebuschi 1997:288), baina (40b)n, aitzitik, ez dela hala, eta azken kasu honetan, erabilera metonimikoa izanik ere (buru izenarekin maiz gertatzen den bezala, bestalde), Xen burua erreferentziadun espresioa dela. Ikuspegi honetan, (40b) adibideetan Xen burua $* \mathrm{i} / \mathrm{i}$ irazkia ez da bortxatua (eta 44)an bezala aztertzeko da:

$$
\ldots \text { Pello }_{\mathrm{i}} \ldots\left[\mathrm{DSs}_{\mathrm{b}}\left[\text { ber }(e)_{\mathrm{i}}\left[\mathrm{i} \text { burua } a_{\mathrm{k}}\right]\right]-a\right]-k \ldots
$$

(44)an bezalako azterketa batek (40)ko bitxikeria azaltzen du. Elkar izenordea, alderantziz, morfologikoki trinkoa da (sinkronikoki behintzat) eta uztartzen duen DSaren indizea dakar. Horregatik (42) adibidean C hatsarrea bortxatua da eta perpausa agramatikala da.

Horrek erran nahi du Xen burua esapideak, esapide metonimo gisa izan dezakeela beregaintasun sintaktiko bat, eta pentsatzekoa da kausatibo lexikaletarik kanpo ere aurki daitekeela. Horrela gertatzen da ondoko adibideetan, non nire burwa espresioak, subjektua izanik, lehen pertsona denotatzen baitu (ikus OEH, buru sarrera, 2, 672. o.):

Nere buruak ere ematen dit franko lan (Labayen, Euskal-Eguna, 92)

Halaz despeditu nahi nuzuia? / Hebetik ioan gabe ene buruia / egin behar duzu ene nahia (Decheparc, 207)

Gauzak horrela izanik, ez dugu arrazoirik euskal psiko-aditzetako kanpoko argumentua deribatua dela pentsatzeko. Azterketak ez du baztertzen Xen burua espresio anaforikoa objektu posizioan agertzeko aukera. Hain zuzen ere, horrela gertatzen da ondoko adibide parean.

\section{Nire buruak izutu nau}

\section{Nire burua izutu dut}

Hiztun gehienentzat (46-47)ko adibideen interpretazioan alde zerbait bada. Gehienek interpretazio agentiboa aise lotzen diogu (47) adibideari (Artiagoitiaren 2000:110), ${ }^{31}$ eta interpretazio psikologikoa, non batek bere nortasun kontrolagaitzean aurkitzen baitu beldurtzeko arrazoia, (46) adibideari. Gure azterbidearen arabera interpretazioetan agertzen den aldea erabilera metonimikoetarik heldu da. Anaforaren kasuan $*_{\mathrm{i} / \mathrm{i}}$ irazkia indargabetua da eta hari datxezkion interpretazioak osoki lotura sintaktikoen arabera bideratuak dira. Erreferentziadun espresioaren kasuan, berriz, interpretazioa metonimia jokoen arabera bideratua da, agentibotasuna (gaurko hiztunentzat bederen) ${ }^{32}$ bazterturik geratzen delarik.

Orain ikus dezagun psiko-kausatibo horiei dagokien errepresentazioa. Lehen ikusi dugu, euskaraz, egoera fisikoei dagozkien aditzek izenondo bat dutela maiz oinarrian (argal, bero, handi, hil, hotz, lodi, luze, mehe, tiki, zabal, ...).

\footnotetext{
${ }^{30}$ Delako baldintzak dio $[\gamma \ldots \delta \ldots]$ egituran $\gamma$ eta $\delta$ ez direla indizekideak izaten ahal, non ez den $\delta \gamma$-ren burua (Chomsky 1981:212, eta 63 oh.). Hemengo kasuari aplikatuz, $\gamma$ sintagma bere burua izanik, bere-k ezin izan dezake haren indizea; buru izenak, aldiz, indize hori du, zeren bera baita sintagmako burua.

31 Zeri erraten zaion agentibo, bestalde. Ez du irudi kasu honetan arazleak bere burua nahitara izutu behar duela. Alabaina, (45a) normalean onartzen duten hiztunek (47) nahiago dute testuinguru honetan : Autobidean, autoa bide bustian lerraturik, istripu bat, oso larria, gertatzer zaizu. Izutu zara. Nola nahiago zenuke erran orduan egoera hori aipatuz: (46) ala (47)?

32 Itxura guztien arabera, (45b) adibidea honen kontra doa. Haatik, enetzat, eta baita galdatu diedan lagunentzat ere, dudazkoa da adibidea, (45a)koa ez bezala. Badirudi, gaurko euskaran erabilera metonimikoa zail gertatzen dela espresioari interpretazio agentiboa ematen zaionean.
} 
Psiko-egoera adierazten duten izenetarik sortu aditzek ere egoera aldaketa adierazten dute, baina gutiz gehienetan izen batetik eratorriak dira (ahalke, arrangura, asper, beldur, griña, haserre, izu, kezka, poz, ...). ${ }^{33}$ Nahiz maizenik ${ }^{34}$ ez duten erabilera atributiborik (??gizon ahalkea / * gizon arrangura / *gizon beldurra ...), perpaus askriptiboetan egoera predikatu gisa erabiliak direnean, izan aditzarekin ager daitezke izen horiek (ahalke izan, arrangura izan, beldur izan, haserre izan, ...). Bestela, batez ere izen hutsaren orde izen sintagma denean, postposizio batekin aurkitzen ditugu (Zabala :993:544-548):

(48a) Beldur / ahalke / arrangura / haserre / lotsa ... naiz

(48b) Kezkaz / beldurrez / pozin̆ nago

\section{(48c) Haserre gorrian naiz}

Gauzak horrela izanez, proposatuko dugu mota horietako psiko-kausatiboen deskonposizioan ${ }^{35}$ ere PospS aukeratzen duen aldaketa aditza badela, ${ }^{36}$ aldaketa psiko-egoera berri batean sartzean datzalarik: x-k ARAZI [y BIHUR z PSIKOEGOERAN]. ${ }^{37}$ Azterketa horretan, Maddik Pello beldurtu du bezalako perpaus bateko predikatuaren azpian PospS bat aurkitzen da ; honen burua isila da, eta hari inkorporatu zaio beldur izena buruz-buruko mugimendu batean, gero aitzina segituko dena Araz bururaino.

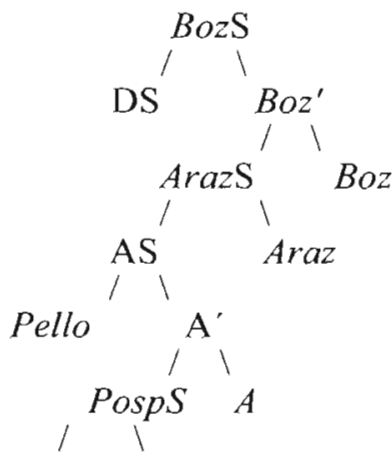

${ }^{33}$ Erran gabe doa, izenondoetarik sortu psiko-aditzak ere badirela: alegeratu, goibeldu, tristetu, .. Deskonposizio lexikala kasu horietan gardena da.

${ }^{34}$ Zenbait izenekin aukera agertzen da halere: gizon haserrea.

${ }^{35}$ Izenondo bat inkorporatua delarik (alegeratu, sumindu, tristetu, ...) izenondoa inkorportazen da noski, egoera aldaketa arruntetan bezala; cf. (18).

36 Artiagoitiak (kp.) oharraratzen dit azterketa horrek *ahalkez(ta)tu edo *lotsaz(la) $t u$ bezalako aditz eratorriak aurrikusten dituela, ez baita halakorik. Galda daiteke ez ote litzatekeen egokiago horrelakoetan izena bera hartzea oinarri gisa (posposiziorik sarrarazi gabe) izen horiek egoera predikatuak izan baitaitezke. Bide hau proposatzen dute AOPZek (2000:437) aditz horien egitura lexiko-semantikoa honela aurkeztuz:

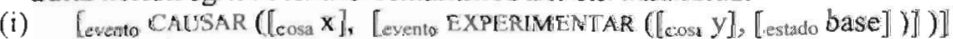

Nola azterkatzen diren egoera predikatuak. Hemengo proposamenean, posposizio baten izateari lotzen zaio interpretazioa, izerdi izan (izerdi naiz), marranta izan (marranta naiz) edo lo izan (lo naiz) predikatuei aplika dakiekeen azterketa psiko-aditzetan ere baliatuz (cf. ikara(n) naiz). Posposizioen gauzatze fonologikoa arazo berezitzat hartzen dut hemen. Horrela utziko dut kontua, baina dudarik batere gabe azterketa sakonagoa merezi luke.

${ }^{37}$ Bakerrek (1997) beste azterbide bat proposatzen du. $x$ frightens $y$ honela azterkatzen du:

(i) $\mathrm{x}$ CAUSE [[FEAR (of $\mathrm{x}$ )] GO TO $\mathrm{z}]$

Azterketa honetan, psiko-kausatiboak emozio baten toki-aldaketa gisa agertzen dira, eta haietako esperientzorea (z) GO predikatuari dagokion lokalizatzaile gisa. 


\section{Posp \\ beldur $\quad-\varnothing$}

\section{Araz eta Boz buruak}

Orain artinoko aurkezpenean, arazo bat ez dugu aipatu: kausazio egitura kausazio buruarekin lotu dugu, argiki adierazi gabe zer lotura izan zitekeen kausazio buru horren eta egitura iragankorretako Boz (edo $a$ ) buruaren artean. Pylkkänenek (2002) hurbiletik aztertzen du zer harreman mota den morfologia kausatiboaren eta kanpoko argumentua izatearen artean, adieraztera emanez ez dabiltzala beti bi gauzak elkarrekin. Oharrarazten du japonierazko kausatibo adbertsatiboetan eta finlandierazko kausatibo gurarizkoetan, kausazioaren morfologiak aditzaren balentzia aldatu gabe utz dezakeela (perpausa halere kausatiboa izanik). Ikus finlandierazko ondoko adibideak:

(50a) Maija laula -a
Maija.NOM kantatu-3sg
Marija kantatzen ari da

(50b) Maija-a laula -tta -a
Maija-PART kantatu-ARAZI-3

(Pylkkänen 2002, (168) adib.)

Maijak kantatu gogo du

Ikus daitekeenaz, kausazioari dagokion morfema ( $t$ ta) gaineratuz, aditzak ez du argumentu gehiago hartzen. Bizkitartean, kausazioaren morfologiak kausazio ebento bat adierazten du inplizitua dena eta galdera batekin agerraraz daitekeena (Pylkkänen 2002, (174) adib.):

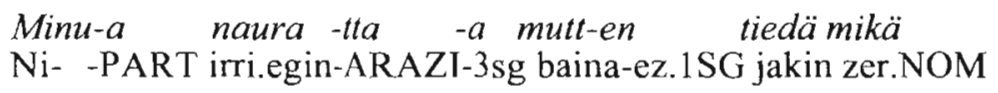

Zerbaitek irri egiteko gogoa ematen dit, baina ez dakit zerk

(51) adibidean, morfologia kausatiboa agertzen da, subjektua (50b)n bezala partitiboan izanik. Halere, perpausaren bigarren partean galdera hitzarekin agerrarazten da kausazioari dagokion galdera hitza (mikä). Ohargarria da galdera hitzak ezin adieraz dezakeela agente bat:

$$
\begin{aligned}
& \text { *Minu-a naura-tta -a mutt-en tiedä kuka } \\
& \text { Ni- PART irri.egin-ARAZI-3sg baina-ez.1SG jakin nor.NOM } \\
& \text { Zerbaitek irri egiteko gogoa ematen dit, baina ez dakit nork }
\end{aligned}
$$

Horregatik, Pylkkänenek (2002) ondorioztatzen du kausazioak ez dakarrela beti kanpo argumentua berekin, eta horretaz komeni dela Araz burua eta kanpo argumentua dakarren burua (Voice haren lanetan) elkarretarik bereiztea.

Zenbait hizkuntzatan, ordea, kausatibo lexikalak zero morfologiaren bidez adierazten dutenetan, kausazio lexikala ez da kanpoko argumenturik gabe gertatzen ahal. Ingelesean hala da, baita euskaran ere, non buru bakar batean biltzen baitira bi buruak. Boz bilketa (Voice-bundling) deitzen du Pylkkänenek egoera hori. (53) erakusten da nola gelditzen den kausatibo lexila baten errepresentazioa ikuspegi horretan: 


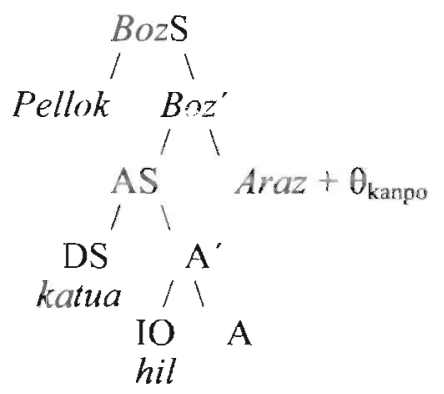

(53)an ikus daitekeenaz, kanpo argumentua dakarren Boz buruari Araz burua lotzen zaio, eta kausazioa eta kanpo argumentua izatea guztiz lotuak dira, finlandieran edo japonieran ez bezala. Kontuan har bedi, aditz kausatiboen egitura hau gaineratiko aditz iragankorrenaren antzekoa dela. Horrela esplika daiteke euskarari buruzko zenbait lanetan, hala nola AOPZ (2000:442), hemen aldizkatze iragangaitzik ez izanik aditz kausatiboen artean sartzen ez ditugun aditz eratorri batzuk kausazioaren bidez azaltzea (babestu, zigortu, ... bezalako aditzen egitura lexiko-emantikoan, adibidez).

7. Hondar hitz gisa, euskaraz kausazio aldizkatze lexikala nola gertatzen den laburbiltzeko hauxe erranen dugu. Aldaketa aditzekin agertzen da: subjektuaren izaeran, itxuran, psiko-egoeran edo lokalizazioan, aldaketa bat adierazten duten aditzekin. Erroei lotuak izan daitezkeen idiosinkrotismoa bazterrean utzirik, oso erregularra da aldizkatze lexikala euskaraz kasu horietan.

Hiru deskonposizio eredu nagusi aurkitu ditugu, non hiruetan Araz buruak AS bat aukeratzen baitu, honen burua egoera aldaketa edo toki aldaketa izanki: lehenean (18), BIHUR aditzak izenondoa edo izena aukeratzen du eta inkorporatzen, bestelako morfologiarik agerrarazi gabe (edertu, handitu, haurtu, ...) ; bigarrenean (49), aditz berak PospS bat aukeratzen du, zeinen buru isilak inkorporatzen baitu bere osagarriaren burua: psiko-kausatiboekin bereziki aurkitu dugu erabide hau (ahalketu, beldurtu, poztu, ...), nahiz bestelakoekin ere kausi daitezkeen (lilitu, ...); hirugarrenaren kasuan (34), JOAN predikatuak aukeratzen du berezko norabidea adierazten duen PospS bat (adlatiboa) edo adberbio bat (atera, etxeratu, hurbildu, ...).

Euskarak, ingelesak bezala, bateratzen ditu kausazioa adierazten duen burua (Araz deitu duguna) eta kanpo argumentua dakarrena (hemen Boz deitua), segurenaz ere zerbait ikustekoa baitu honek hizkuntza horietan kausazio aldizkatzeetan kausazio buruak duen zero morfologiarekin.

\section{Bibliografia}

Alberdi, X. Bidean. 'Euskal aditz mailegatuen erregimena: hurbilketa', Lafitteren mendemugako biltzarreko aktak, Baiona, 20-21/09/2001, Iker 13, Euskaltzaindia- IKER, Bilbo.

Alsina, A. 1992. 'On the Argument Structure of Causatives', Linguistic Inquiry, 23-4, 517-557.

Artiagoitia, X. 1995. 'Garri atzizkiaren izaera bikoitzaz: zergatik den maitagarria bezain mingarria', ASJU XXIX-2, 355-405.

Artiagoitia, X. 2000. Hatsarreak eta Parametroak lantzen, EHU \& Arabako Foru Aldundia. 
Azkarate M., Odriozola J.C., Perez E. \& Zabala I. [AOPZ] 2000. 'Análisis de los afijos del Vasco: el sufijo - $t u$, L. Gràcia Solé, M.T. Cabré Castellví, S. Varela Ortega, M. Azkarate Villar \& al. (arg.) Configuración morfológica y estructura argumental: léxico y diccionario, EHUko argitalpen zerbitzua, 436-459.

Baker, M. 1988. Incorporation theory, University of Chicago Press, Chicago.

Baker, M. 1996. 'On the Structural Position of Themes and Goals', J. Rooryck \& L. Zaring (arg.) Phrase Structure and the Lexicon, 7-34, Kluwer, Dordrecht.

Baker, M. 1997. 'T hematic roles and syntactic structure', L. Haegeman (arg.) Elements of grammar, 137-178, Kluwer, Dordrecht.

Belletti, A. \& Rizzi, L. 1988. 'Psy-verbs and Theta-Theory', Natural Language and Linguistic Inquiry, 6, 291-352.

Borer, H. 1994. 'The projection of arguments', E. Benedicto and J. Runner (arg.) University of Massachusetts Occasional Papers in Linguistics. 17.

Borer, H. 1993. 'The inchoative-causative alternation: a case study in Parallel Morphology', The Linguistic Review 8.

Chierchia, G. 1989. 'A semantics for unaccusatives and its consequences', esku-izkribu argitaratugabea, Cornell University, Ithaca, NY.

Chomsky, N. 1981. Lectures on Government and Binding, Foris, Dordrecht.

Chomsky, N. 1995. The Minimalist Program, MIT Press, Cambridge, MA, \& Londres.

Comrie, B. 1989. Language Universals and Linguistic Typology, Basil Blackwell, Oxford.

Deustuko Mindegia 1989. 'Inkorporazioa perpaus kausatiboetan', P. Salaburu (arg.), Sintaxi teoria eta euskara, EHU, Donostia, 87-119.

Dixon, R. M. W. 2000. 'A Typology of causatives: form, syntax and meaning', R.M.W. Dixon \& A.Y. Aikhenwald, Changing valency. Case studies in transitivity, Cambridge University Press, Cambridge, 30-83.

Dowty 1979: D. Dowty, Word Meaning and Montague Grammar, Reidel, Dordrecht.

Dowty, D. 1991. 'Thematic Roles and Argument Selection', Language, 67-3, 547-619.

EGLU-II (Euskal gramatikaren lehen urratsak, bigarren tomoa). 1987. Gramatika batzordea. Euskaltzaindia. Bilbo.

Etxepare, R. Bidean. 'Valency and argument structure in the Basque verb', J.I. Hualde \& J. Ortiz de Urbina (arg.), A grammar of Basque (bidean), 4.1. kapitulua.

Fodor, J. 1970. 'Three Reasons for not Deriving 'kill' from 'cause to die', Linguistic Inquiry, 1, 429- 438.

Folli R. \& Harley, H. Bidean. 'Consuming Results in Italian \& English: Flavors of $v^{c}$, P. Kempchinsky \& R. Slabakova (arg.) Aspect Book Title, 125, Kluwer, Herri Behereak.

Grimshaw, J. 1990. Argument Structure, MIT Press, Cambridge, MA.

Hale, K. \& Jay Keyser S.J. 1993. 'On argument structure and the lexical expression of syntactic relations, K. Hale and S.J. Keyser (arg.) The View from Building 20: Essays in Linguistics in Honor of Sylvain Bromberger, 53-109, MIT Press, Cambridge, MA. 
Halle, M. \& Marantz, A. 1993. 'Distributed Morphology and the Pieces oflnflection', K. Hale and S.J. Keyser (arg.) The View from Building 20: Essays in Linguistics in Honor of Sylvain Bromberger, 111-176, MIT Press, Cambridge, MA.

Jackendoff, R. 1997. The Architecture of the language faculty, Cambridge, MIT Press, MA.

Kratzer, A. 1996. 'Severing the External Argument from its Verb', J. Rooryck \& L. Zaring (arg.) Phrase Structure and the Lexicon, 109-138, Kluwer, Dordrecht.

Lafitte, P. 1944. Grammaire basque. Dialecte navarro-labourdin, 1962ko argitalpen zuzendua, fac-similea, Elkarlanean, Baiona.

Labelle, M. 1990. "Unaccusatives and Pseudo-Unaccusatives in French", Proceedings of the North East Linguistic Society 20, 2. liburukia, 303-317, Pittsburgh.

Laka, I. 1993. "Unergatives that Assign Ergative, Unaccusatives that Assign Accusative', J. Bobaljik \& C. Phillips (arg.), Papers on Cas Agreement I, MIT Working Papers in Linguistics, 18, 149-172, Cambridge, MA.

Lakoff, G. 1968. 'Some Verbs of Change and Causation', S. Kuno (arg.) Mathematical Linguistics and Automatic Translation, Aiken Computation Laboratory, Harvard University, Cambridge, MA.

Levin, B. 1983. On the Nature of Ergativity, Ph-D, MIT Press, Cambridge, MA.

Levin, B. 1989. 'The Basque Verbal Inventory and Configurationality', L. Maracz \& P. Muysken, Configurationality, 39-62, Foris, Dordrecht.

Levin, B. 1993. English Verb Classes and Alternations. A Prelimenary Investigation, The University of Chicago Press, Chicago eta Londres.

Levin, B. \& Rappaport Hovav, M. 1995. 'Unaccusativity. At the SyntaxLexical Semantics Interface', MIT-Press, Cambridge, MA.,

Marantz, A. 1997. 'No escape from Syntax: Don't try morphological analysis in the privacy of your own lexicon', A. Dimitriadis \& L. Siegel (arg.) University of Pennsylvania Working Papers in Linguistics, 4-2, 221-225, University of Pennsylvania, Philadelphia.

McGinnis, M. 2000. 'Event heads and the Distribution of Psy-roots', A. Williams \& E. Kaiser (arg.) Current work in linguistics: University of Pennsylvania Working Papers in Linguistics, 6-3, 107-144.

Megerdoomian, K. 2002. Beyond Words and Phrases: A Unified Theory of Predicate Composition, Ph-D, UCLA.

Mendikoetxea, A. 1999. 'Construcciones inaccusativas y pasivas', I. Bosque \& V. Demonte (Zuzend.) Gramática Descriptiva de la Lengua Española, 25. kapitulua, 2. liburukia, 1575-1629, Espasa, Madrid.

Miyagawa, S. 1989. Structure and Case Marking in Japanese, Syntax and Semantics 22, Academic Press, Londres.

OEH (Orotariko Euskal Hiztegia). 1987-2001. 13 liburuki, peb-arte. Luis Michelena. Euskaltzaindia. Desclée De Brouwer \& Mensajero, Bilbo.

Ortiz de Urbina, J. 1989. Parameters in the Grammar of Basque, Foris, Dordrecht.

Oyharçabal, B. 1993. 'Notion d'objet et cas absolutif en basque', Le gré des langues, 5, ii-xxi, Paris. 
Oyharçabal, B. 1994. 'Contribution de la comparaison typologique à une analyse des rapports ergativité-(in)transitivité en basque', J-B. Orpustan (zuzend.) La langue basque parmi les autres, Baionako 1993/09/27-28ko biltzarreko aktak, 115-147, Izpegi, Baigorri.

Perlmutter, D. 1978. 'Impersonal passives and the Unaccusatives Hypothesis", Proceedings of the Fourth Annual Meeting of the Berkeley Linguistics Society, 157-189, Berkeley Linguistics Society, Berkeley, University of California.

Perlmutter, D. \& Postal, P. 1984. 'The1-Advancement Exclusiveness Law', D. Perlmutter \& C. Rosen (arg.) Studies in Relational Grammar 2, University of Chicago Press.

Pesetsky, David. 1995. Zero Syntax. MIT Press, Cambridge, MA.

Pustejovsky, J. 1995. The Generative Lexicon, MIT Press, Cambridge, MA.

Pinker 1989. Learnability and Cognition: The Acquisition of Argument Structure, MIT Press, Cambridge, MA.

Pylkkänen, 1999. 'On Causativity and Causation', C. Tenny \& J. Pustejovsky (arg.) Events as Grammaticals ObjectsI, CSLI, Publications.

Pylkkänen, L. 2001 'Argument of causatives', esku-izkribua, MIT, Cambridge, MA.

Pylkkänen L. 2002. Introducing Argument, Ph-D, MIT, Cambridge, MA.

Rijk, R. de- , (arg.). 'L'antipassif basque et l'hypothèse de Levin', Lapurdum, 7 , Baiona.

Rebuschi, G. (1984). Structure de l'énoncé en basque, SELAF, Paris.

Rebuschi, G. (1985) 'Théorie du liage et langues non-configurationnelles: Quelques donnéees du basque navarro-labourdin', Euskera 1985, 30-2, 389 433.

Rebuschi, G. 1995. 'Weak and Strong Genitive Pronouns in Northern Basque : A diachronic Perspective', J. I. Hualde, J.A. Lakarra \& R.L. Trask (arg.) Towards a History of the Basque Language, Johns Benjamins, Amsterdam / Philadelphia, 313-356.

Rebuschi, G. 1997. 'Absolute and Relatized Locality in the Binding Theory', G. Rebuschi, Essais de linguistique basque, ASJUren gehigarriak, Euskal Herriko Unibertsitatea - Universidad del País Vasco, Bilbo, 279-300.

Reinhart, T. \& Siloni, T. Bidean. 'Against the Unaccusative Analysis of Reflexives', Studies in Unaccusativity: The Syntax-lexicon Interface, Cambridge University Press.

Safir, K. 1996. 'Semantic Atoms of Anaphora', Natural Language \& Linguistic Theory, 14-3, 545-589.

Sarasola, I. 1977. 'Sobre la bipartición inicial en el análisis en constituyentes', $A S J U, \mathrm{XI}, 51-90$.

Tenny, C. 1994. Aspectual Roles and the Syntax-Semantics Interface, Kluwer, Dordrecht.

Williams, E. 1981. 'On the notions "Lexically related" and "Head of a word", Linguistic Inquiry, 12-2, 245-274.

Zabala, I. 1993. Predikazioaren teoriak gramatika sorizailean (euskararen kasua), doktoregoko tesi argitaratugabea, EHU. 